\title{
Resistance of Manihot esculenta and its intraspecific hybrids to the whitefly Aleurothrixus aepim (Hemiptera: Aleyrodidae)
}

\author{
Willem Henrique Lima( ${ }^{(1)}$, Rudiney Ringenberg ${ }^{(2)}$, Marilene Fancelli(2) and Carlos Alberto da Silva Ledo(2)
}

(1)Universidade Federal do Recôncavo da Bahia, Programa de Pós-Graduação em Ciências Agrárias, Rua Rui Barbosa, no 710, Centro,

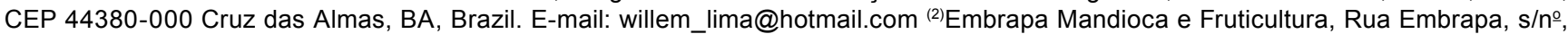
Caixa Postal 007, CEP 44380-000 Cruz das Almas, BA, Brazil. E-mail: rudiney.ringenberg@embrapa.br, marilene.fancelli@embrapa.br, carlos.ledo@embrapa.br

\begin{abstract}
The objective of this work was to evaluate the resistance of Manihot esculenta and its hybrids (M. esculenta $\mathrm{x}$ M. esculenta ssp. flabellifolia and M. esculenta $\mathrm{x}$ M. esculenta ssp. peruviana) to the whitefly (Aleurothrixus aepim). The trial was carried out in a greenhouse from October to December 2015, and it was based on a completely randomized design with eight treatments (eight genotypes). The evaluated variables and replicates were the following: duration of the developmental phases of the whitefly (nine replicates); nymphal viability (nine replicates); egg viability (five replicates); period of incubation (five replicates); and number of eggs (three replicates). Trichome counting (nine replicates) and the colorimetric analysis (nine replicates) were also performed. The 'Ecuador 72 ' genotype promoted the lowest value for viability of the immature development phase (44.89\%), showing an antibiosis effect on A. aepim. The FLA 003 genotype (a wild accession of M. esculenta ssp. flabellifolia) and the F1 011 (M. esculenta x M. esculenta ssp. flabellifolia) and PE 001 (M. esculenta x M. esculenta ssp. peruviana) hybrids showed resistance by antixenosis and were the less preferred for oviposition. The 'Ecuador 72', FLA 003, F1 011, and PE 001 genotypes can be used as sources to obtain new, resistant cultivars of cassava.
\end{abstract}

Index terms: antibiosis, antixenosis, pests, varietal resistance, wild cassava.

\section{Resistência de Manihot esculenta e seus híbridos intraespecíficos à mosca-branca Aleurothrixus aepim (Hemiptera: Aleyrodidae)}

\begin{abstract}
Resumo - O objetivo deste trabalho foi avaliar a resistência de Manihot esculenta e de seus híbridos (M. esculenta $\mathrm{x}$ M. esculenta ssp. flabellifolia e M. esculenta $\mathrm{x}$ M. esculenta ssp. peruviana) à mosca-branca (Aleurothrixus aepim). O ensaio foi realizado em estufa, de outubro a dezembro de 2015, e foi baseado em delineamento inteiramente casualizado com oito tratamentos (oito genótipos). As variáveis e repetições avaliadas foram as seguintes: duração das fases de desenvolvimento da mosca-branca (nove repetições); viabilidade da ninfa (nove repetições); viabilidade da fase de ovo (cinco repetições); período de incubação (cinco repetições); e número de ovos (três repetições). A contagem do número de tricomas (nove repetições) e a análise colorimétrica (nove repetições) também foram realizadas. O genótipo 'Ecuador 72' apresentou o menor valor de viabilidade da fase jovem de desenvolvimento (44,89\%), o que mostra o efeito de antibiose sobre $A$. aepim. O genótipo FLA 003 (um acesso silvestre de M. esculenta ssp. flabellifolia) e os híbridos F1 011 (M. esculenta x M. esculenta ssp. flabellifolia) e PE 001 (M. esculenta x M. esculenta ssp. peruviana) apresentaram níveis de resistência caracterizada por antixenose e foram os menos preferidos para oviposição. Os genótipos 'Ecuador 72', FLA 003, F1 011 e PE 001 podem ser usados como fontes para a obtenção de novas cultivares resistentes de mandioca.
\end{abstract}

Termos para indexação: antibiose, antixenose, pragas, resistência varietal, mandioca silvestre.

\section{Introduction}

Arthropod pests are considered a severe threat to cassava crops (Bellotti et al., 2012). Among these, the highest yield losses are caused by whiteflies Aleurothrixus aepim (Goeldi), Aleurotrachelus socialis Bondar, and Bemisia tuberculata Bondar -, mainly in the Americas and Africa (Bellotti, 2008; Bellotti et al.,
2012). In Brazil, the two common whitefly species are A. aepim and B. tuberculata.

Whiteflies can negatively affect cassava through direct feeding, causing root yield reductions, and as vectors of viruses (Anderson \& Morales, 2005; Bellotti et al., 2012). Host plant resistance (HPR) to whiteflies is rare in cultivated plants (Bellotti \& Arias, 
2001). Thus, given the severity of the damage caused by these insects, research and plant breeding programs have been trying to develop resistant cultivars (Bellotti et al., 2012).

Wild species of Manihot stand out as important sources of resistance to arthropod pests, such as whiteflies (A. socialis), mites [Mononychellus tanajoa (Bondar)] (Boaventura et al., 2015) and coccids (Phenacoccus herreni Cox \& Williams) (Burbano et al., 2007). In addition, there is evidence that genes of wild species of Manihot that are resistant to A. socialis can be transferred to Manihot esculenta Crantz (Akinbo et al., 2012), making it possible the study of the resistance of wild cassava species.

The objective of this work was to evaluate the resistance of $M$. esculenta and its different hybrid accessions ( $M$. esculenta x $M$. esculenta ssp. flabellifolia; $M$. esculenta x $M$. esculenta ssp. peruviana) to A. aepim.

\section{Materials and Methods}

The trials for the evaluation of resistance were carried out from October to December 2015, under greenhouse conditions at $25.9 \pm 0.9^{\circ} \mathrm{C}$ and relative humidity of $66.6 \pm 3.3 \%$, at $12^{\circ} 40^{\prime} 39^{\prime \prime} \mathrm{S}, 39^{\circ} 06^{\prime} 23^{\prime \prime} \mathrm{W}$, at $226 \mathrm{~m}$ altitude. Cuttings for plant propagation came from experimental areas and from a cassava germplasm bank. Eight genotypes were evaluated, including four hybrids from crosses of M. esculenta with M. esculenta ssp. flabellifolia (F1 011, F2 015, F3 008, F4 002), one hybrid from a cross of M. esculenta with $M$. esculenta ssp. peruviana (PE 001), a wild accession of M. esculenta ssp. flabellifolia (FLA 003), and two cultivars of M. esculenta ('Ecuador 72' and 'Cigana Preta').

The development time and survival rate of A. aepim was evaluated in greenhouse, and it was based on a completely randomized design (CRD), with eight treatments (eight genotypes), and nine replicates; each experimental plot was composed of 25 insects for a total of 225 insects per genotype. To obtain the eggs, 20 unsexed adults of $A$. aepim were placed in clip cages (2.5 $\mathrm{cm}$ diameter, $2.0 \mathrm{~cm}$ depth) on the abaxial face of three completely expanded cassava leaves counted from the apex of each plant. This was done in triplicate (three plants) on the accessions of Manihot. Adult insects remained confined for 24 hours to allow of oviposition. After this period, the cages were removed, the eggs were randomly selected, and 30 eggs were left per leaf. After eclosion, 25 nymphs were randomly selected (and the remaining ones were eliminated) for further development, for a total of 225 individuals per genotype. Eggs and nymphs were observed under a magnifying glass (60X). Data collection was made daily.

Near the emergence period of adults, in the fourth instar, a voile cage was placed around the infested leaves, and the emergence day of each individual was determined. The adults found daily were removed from the cage, counted, and sexed with the aid of a stereoscopic microscope, and the sex ratio (SR) was then determined, based on Silveira Neto et al. (1976), according the following formula: $\mathrm{SR}=$ number of females / (number of females + number of males).

The survival rate (viability) of the immature stage was determined by the relation between the number of nymphs that reached the adult phase and the number of hatched nymphs. Subsequently, couples of whiteflies generated on each genotype were confined to leaves of the same genotype for the evaluation of the incubation period and the viability of the egg phase. This study was based on five replicates (20 eggs per replicate), for 100 eggs per genotype.

The preference for oviposition was evaluated by a free-choice test and was based on a completely randomized design (CRD), with eight treatments (eight genotypes) and three replicates. The eight treatments (F1 011, F2 015, F3 008, F4 002, PE 001, FLA 003, 'Ecuador 72 ' and 'Cigana Preta') were randomly arranged in a circle, inside a $1.00 \times 0.70 \times 0.70 \mathrm{~m}$ cage covered with anti-aphid screen. Approximately five hundred unsexed $A$. aepim adults from the wild accession Manihot carthagenensis were released in the center of each cage, equidistantly from the genotypes. Egg laying was evaluated after 48 hours of exposure, on three apical leaves, completely expanded, from each plant. The number of eggs on the abaxial face of each leaf was counted using a stereoscopic microscope.

To investigate if leaf surface color of the different cassava genotypes interferes with $A$. aepim oviposition, color readings were made using a Minolta CR400 Chroma Meter (Konica Minolta Sensing Americas, New Jersey, USA) colorimeter with a CIE reading system. The evaluated parameters were luminosity (L) and the chromatic coordinate information "a" and 
"b", for which "a" corresponds to an axis that varies from red to green, and "b" to an axis that varies from yellow to blue. The evaluation was made with the same eight treatments with nine replicates, based on a completely randomized design (CRD). The central region of the abaxial surface of the leaf was evaluated, excluding the midvein of the leaflets, for the first three completely expanded leaves (at the apex) of three plants per genotype. Each leaf was considered a replicate. A Spearman correlation analysis was performed with the variables a* (colorimetric analysis - intensity of green color) $\mathrm{x}$ number of eggs, using the statistical program SAS (SAS Institute Inc., Cary, NC, EUA).

From the same leaf samples used for the freechoice test, trichome densities were assessed under a stereoscopic microscope (64X). Counts were made on the abaxial surface of the central leaflet of each leaf within two circular areas. Each area had $3 \mathrm{~mm}$ diameter $\left(7.07 \mathrm{~mm}^{2}\right)$, and the counts were taken on each side of the midrib. The mean value of two counts per leaflet was used. The counts were made on three completely expanded leaves of three plants per genotype, and each leaf was considered a replicate, totaling 18 records per genotype. Using the trichome density data, a Spearman correlation analysis was performed with for the number of trichomes and the number of eggs, using the statistical program SAS (SAS Institute Inc., Cary, NC, EUA).

\section{Results and Discussion}

The development time of $A$. aepim was significantly affected by the Manihot genotypes, and three distinct groups were formed (Table 1). The hybrid PE 001 had the longest incubation period, in comparison to F1 011, F3 008. The wild accession FLA 003 ranked into the group of genotypes with the lowest incubation periods. The intermediary group included the genotypes F2 015, F4 002, 'Ecuador 72' and 'Cigana Preta'. These incubation values are higher than the reported one -6.5 days on the cassava cultivar Cascuda - by Gazola et al. (2009), for the same species of whitefly, at $25 \pm 3^{\circ} \mathrm{C}$. The hybrid PE 001 stood out from the others because, on this genotype, the higher values of the insect-egg incubation time increased the time for the whitefly to complete its cycle.

For nymph development, the hybrid F4 002 stood out for showing the highest mean for development time (first instar to adult) in comparison to the other Manihot genotypes, except for the second instar. However, for the first instar, F4 002 ranked into the same group as FLA 003 and 'Ecuador 72'. For the third instar, F4 002 remained in the same group of FLA 003 (Table 1). The individuals that developed on F4 002 remained with the highest means for incubation time and development time (egg to adult). For these individuals, development time was 4.67 days longer (or $18.09 \%$ higher) than that of the genotype F1 011, which showed the lowest mean development time. The same group included the genotypes 'Cigana Preta' and the hybrid F3 008, which were more susceptible than the remaining treatments. The genotypes 'Ecuador 72', F2 015, PE 001, and FLA 003 had intermediary duration values (Table 1). A delay in the development time was a desirable effect caused by the genotype F4 002, since

Table 1. Development time (days) of Aleurothrixus aepim on Manihot genotypes, under greenhouse conditions at $25.9 \pm 0.9^{\circ} \mathrm{C}$ and $66.6 \pm 3.3 \%$ relative humidity ${ }^{(1)}$.

\begin{tabular}{|c|c|c|c|c|c|c|c|}
\hline \multirow[t]{2}{*}{ Genotype } & \multicolumn{7}{|c|}{ Insect phase period (days) } \\
\hline & Egg* & First instar** & Second instar** & Third instar** & Fourth instar** & First instar to adult phase** & Total** \\
\hline Cigana Preta & $9.70 \pm 0.5 b$ & $3.95 \pm 0.4 \mathrm{c}$ & $3.19 \pm 0.2 \mathrm{c}$ & $3.39 \pm 0.2 \mathrm{~b}$ & $6.34 \pm 0.4 \mathrm{c}$ & $16.87 \pm 0.9 \mathrm{c}$ & $26.55 \pm 0.9 \mathrm{c}$ \\
\hline Ecuador 72 & $9.62 \pm 0.4 \mathrm{~b}$ & $5.40 \pm 0.4 \mathrm{a}$ & $3.41 \pm 0.1 \mathrm{c}$ & $3.15 \pm 0.1 \mathrm{c}$ & $7.07 \pm 0.3 \mathrm{c}$ & $19.01 \pm 0.3 b$ & $28.65 \pm 0.5 b$ \\
\hline F1 011 & $8.48 \pm 0.2 \mathrm{c}$ & $4.09 \pm 0.1 \mathrm{c}$ & $3.25 \pm 0.2 \mathrm{c}$ & $3.18 \pm 0.1 \mathrm{c}$ & $6.87 \pm 0.8 \mathrm{c}$ & $17.33 \pm 0.7 \mathrm{c}$ & $25.82 \pm 0.7 \mathrm{c}$ \\
\hline F2 015 & $9.39 \pm 0.5 b$ & $4.62 \pm 0.5 b$ & $3.34 \pm 0.2 \mathrm{c}$ & $3.40 \pm 0.3 b$ & $7.74 \pm 1.3 b$ & $18.82 \pm 1.6 \mathrm{~b}$ & $28.24 \pm 1.8 b$ \\
\hline F3 008 & $8.88 \pm 0.9 \mathrm{c}$ & $4.19 \pm 0.4 \mathrm{c}$ & $3.31 \pm 0.3 \mathrm{c}$ & $3.38 \pm 0.2 b$ & $6.87 \pm 0.5 \mathrm{c}$ & $17.65 \pm 1.1 \mathrm{c}$ & $26.46 \pm 1.6 \mathrm{c}$ \\
\hline F4 002 & $9.54 \pm 0.4 \mathrm{~b}$ & $4.84 \pm 0.9 \mathrm{a}$ & $3.50 \pm 0.4 \mathrm{~b}$ & $3.89 \pm 0.4 \mathrm{a}$ & $8.78 \pm 2.1 \mathrm{a}$ & $20.94 \pm 2.7 \mathrm{a}$ & $30.49 \pm 2.6 \mathrm{a}$ \\
\hline PE 001 & $10.42 \pm 0.2 \mathrm{a}$ & $4.53 \pm 0.1 \mathrm{~b}$ & $3.25 \pm 0.2 \mathrm{c}$ & $3.41 \pm 0.2 b$ & $6.99 \pm 0.7 \mathrm{c}$ & $18.13 \pm 0.9 \mathrm{c}$ & $28.59 \pm 0.8 b$ \\
\hline FLA 003 & $8.89 \pm 0.5 \mathrm{c}$ & $5.16 \pm 0.7 \mathrm{a}$ & $3.77 \pm 0.3 \mathrm{a}$ & $3.69 \pm 0.4 \mathrm{a}$ & $6.60 \pm 0.4 \mathrm{c}$ & $19.16 \pm 0.6 b$ & $28.24 \pm 0.8 b$ \\
\hline $\mathrm{CV}(\%)$ & 6.12 & 11.66 & 8.09 & 8.17 & 14.28 & 7.26 & 4.99 \\
\hline
\end{tabular}


it adversely affected the development of the insect by increasing the time for the whitefly to complete its cycle. According to Lara (1991), when insects require a longer time to complete the immature stage, either the nonpreference for feeding, or antibiosis, or both, are suggested as the resistance type of the plant.

Previous studies reported that on 'Ecuador 72' (observed as resistant to A. socialis) and on the wild accessions of $M$. esculenta ssp. flabellifolia, the whitefly had a longer development time (egg-adult) than on M. esculenta CMC-40 (Carabalí et al., 2010a, 2010b). Likewise, in the present study, A.aepim had higher means of development time on 'Ecuador 72' and on the wild accession FLA 003 than that found on 'Cigana Preta'.

As to egg viability, there was no significant difference for the genotypes evaluated. In relation to the viability of the nymph phase, only insects on 'Ecuador 72' genotype differed from those on the other genotypes (Table 2). The average viability observed for the nymphs of $A$. aepim that developed on 'Ecuador $72^{\prime}$ was $53.16 \%$ lower than that of nymphs that developed on the genotype 'Cigana Preta' which had a high viability. The viability found on 'Ecuador 72' was lower than that found (71.0\%) by Carabalí et al. (2010a) for another species (A. socialis). As the biotic potential of a given species is directly related to the viability, whiteflies developed on 'Ecuador 72' will always show a low value for this parameter. In consequence, the potential of damage might be reduced on this genotype.

The low viability of the immature phase of $A$. aepim on 'Ecuador 72' could be associated to semiochemicals involved in the interaction of this insect pest with the host plant. So, this finding corroborates the results by Ribeiro (2015), who observed that volatiles induced by herbivorous attack (HIPVs) have been shown to be a plant defense mechanism (Dudareva et al., 2006; Maffei, 2010).

As to the nymphal viability of $A$. aepim (Table 2), the values registered for the genotypes evaluated are within the range described by Carabalí et al. (2010a), who observed a survival rate from 69.0 to $81.0 \%$ in $A$. socialis developed on other wild genotype accessions of the same subspecies. These authors report that the plants were resistant to $A$. socialis when considering the combined results of biology and oviposition preference.
The sex ratio was not affected by the different Manihot hosts. For all evaluated genotypes, the sex ratio value exceeded 0.50 , which favors the population growth of A. aepim on these Manihot genotypes. The hybrids F1 011 and F4 002 had the highest sexual ratio (Table 2). It is possible that these genotypes better meet the nutritional needs of the females that demand higher-quality food (Slansky Jr. \& Scriber, 1985). The genotypes 'Ecuador 72', FLA 003 and F2 015 showed a 0.51 sex ratio, which is similar to that reported by Carabalí et al. (2010b) for $A$. socialis on 'Ecuador 72' (0.50).

Different levels of preference for oviposition were detected for A. aepim on Manihot genotypes (Table 3). Two groups were observed according to the preference for oviposition. The insects oviposition preference were higher on 'Cigana Preta', 'Ecuador 72', F2 015, F3 008, and F4 002 (Table 3). The genotype 'Ecuador 72', on which occurred the lowest-nymphal viability of $A$. aepim, was one of the highly oviposited genotypes. Thus, oviposition preference of $A$. aepim was not related to viability of the immature phase on a specific genotype. These results did not corroborate the findings by Carabalí et al. (2010a), who evaluated the whitefly $A$. socialis on cassava. The whitefly $A$. aepim uses hosts other than cassava, for instance, representatives of the families Anacardiaceae, Sapindaceae, Solanaceae (Marsaro Júnior et al., 2015),

Table 2. Mean egg and nymph viability (\%) and sex ratio of Aleurothrixus aepim on the Manihot genotypes, under greenhouse conditions at $25.9 \pm 0.9^{\circ} \mathrm{C}$ and $66.6 \pm 3.3 \%$ relative humidity ${ }^{(1)}$.

\begin{tabular}{lccc}
\hline Genotype & $\begin{array}{c}\text { Egg viability } \\
(\%)^{(2)} \text { ns }\end{array}$ & $\begin{array}{c}\text { Nymph viability } \\
(\%)^{(2)} * *\end{array}$ & $\begin{array}{c}\text { Sex } \\
\text { ratio }\end{array}$ \\
\hline Cigana Preta & 88.07 & $84.44 \mathrm{a}$ & 0.56 \\
Ecuador 72 & 89.42 & $44.89 \mathrm{~b}$ & 0.51 \\
F1 011 & 84.49 & $81.33 \mathrm{a}$ & 0.62 \\
F2 015 & 84.53 & $78.67 \mathrm{a}$ & 0.51 \\
F3 008 & 88.84 & $79.11 \mathrm{a}$ & 0.58 \\
F4 002 & 91.47 & $70.67 \mathrm{a}$ & 0.62 \\
PE 001 & 85.82 & $78.32 \mathrm{a}$ & 0.53 \\
FLA 003 & 88.84 & $78.22 \mathrm{a}$ & 0.51 \\
\hline Coefficient of variation (\%) & 7.40 & 14.96 & 11.47 \\
Standard deviation & \pm 6.78 & \pm 10.48 & \pm 0.06 \\
\hline
\end{tabular}

(1) Means followed by different letters, in the columns, indicate that the genotypes belong to different groups by the Scott-Knott test, at 5\% probability. ${ }^{*}$ and ${ }^{* *}$ Significant at 5 and $1 \%$ probability by the $\mathrm{F}$ test, respectively. ${ }^{\text {nn}}$ Nonsignificant. ${ }^{(2)}$ Data transformed by $\arcsin (\sqrt{ } \%)$. 
Asteraceae, Convolvulaceae, Myrtaceae, Rubiaceae, and Rutaceae (Evans, 2008). Thus, unlike A. socialis, the whitefly $A$. aepim might not select the oviposition sites based on the host quality for larval development.

The group of genotypes that were less preferred for oviposition included FLA 003, the wild accession of M. esculenta ssp. flabellifolia, and the hybrids F1 011 and PE 001 (Table 3), which shows that the wild subspecies and the hybrids tend to be less preferred for oviposition by the whitefly. This is an evidence for the occurrence of an antixenotic effect in these genotypes, corroborating the results reported by Carabalí et al. (2010a) on wild accessions of $M$. esculenta ssp. flabellifolia.

There were differences for trichome densities among the genotypes (Table 3). Some studies have shown that there is not always a correlation between the number of trichomes and the number of eggs oviposited by whiteflies. Prado et al. (2015), who evaluated Bemisia tabaci infestation on a cotton crop, observed a negative correlation; however, for the same crop, there have also been cases where no correlation was found between these two variables (Boiça Jr. et al., 2007; Torres et al., 2007). Although there were differences for the density of trichomes on the leaves of the Manihot genotypes, this did not influence the number of eggs oviposited by $A$. aepim (the Spearman's correlation coefficient was not significant, at $5 \%$ probability, by the $t$ test $=$ -0,1515). Thus, there must be another factor involved in the oviposition preference of $A$. aepim.

Table 3. Mean number of whitefly eggs (Aleurothrixus aepim) and trichomes on leaves of the Manihot genotypes, at $25.9 \pm 0.9^{\circ} \mathrm{C}$ and $66.6 \pm 3.3 \%$ relative humidity ${ }^{(1)}$.

\begin{tabular}{lcc}
\hline Genotype & No. of eggs** & No. of trichomes** \\
\hline Cigana Preta & $135.83 \mathrm{a}$ & $2.33 \mathrm{~d}$ \\
Ecuador 72 & $97.33 \mathrm{a}$ & $31.89 \mathrm{~b}$ \\
F1 011 & $40.17 \mathrm{~b}$ & $21.33 \mathrm{c}$ \\
F2 015 & $79.00 \mathrm{a}$ & $29.83 \mathrm{~b}$ \\
F3 008 & $74.67 \mathrm{a}$ & $39.72 \mathrm{a}$ \\
F4 002 & $76.50 \mathrm{a}$ & $0.94 \mathrm{~d}$ \\
PE 001 & $50.50 \mathrm{~b}$ & $30.00 \mathrm{~b}$ \\
FLA 003 & $49.67 \mathrm{~b}$ & $46.39 \mathrm{a}$ \\
\hline Coefficient of variation (\%) & 26.59 & 27.01 \\
Standard deviation & \pm 20.06 & \pm 6.84 \\
\hline
\end{tabular}

(1)Means followed by different letters, in the columns, indicate that the genotypes belong to different groups by the Scott-Knott test, at 5\% probability. $*$ and $* *$ Significant at 5 and $1 \%$ probability by the $\mathrm{F}$ test, respectively.
In the colorimetric analysis, to measure the intensity of the green color of the leaves (a), the genotypes were statistically separated into two groups: those with a more intense green tonality ('Cigana Preta', 'Ecuador 72', F2 015, F3 008, PE 001, and FLA 003), and those with a less intense green tonality (F1 011 and F4 002) (Table 4).

For the whitefly $B$. tabaci, the attraction to the host is primarily related to color and not odor (Berlinger, 1986; Van Lenteren \& Noldus, 1990). Although Manihot genotypes showed significant differences in the present study, the preference of A. aepim was not related to leaf color because there was no correlation between oviposition preference and intensity of the green color of the leaves (a) (Spearman's correlation coefficient not significant at $5 \%$ probability by the $\mathrm{t}$ test $=-0.2025$ ). However, in a study with $B$. tabaci on cotton, the whitefly preferred to lay eggs on the genotypes that had leaves with a more intense green color (a) (Prado et al., 2015). Some studies have also shown that whiteflies tend to be attracted to yellow (Moreau \& Isman, 2011; Shimoda \& Honda, 2013). Nonetheless, there were no differences for the intensity of yellow (b) between the genotypes evaluated in the present study (Table 4).

For the L variable, which represents the intensity of total luminosity reflected by the leaf surface, three groups were formed. The hybrid F1 011 and the wild accession FLA 003 had middle values for $\mathrm{L}$ that

Table 4. Colorimetric evaluation of the abaxial region of leaves, for eight Manihot genotypes, using the CIE system at temperature of $25.9 \pm 0.9^{\circ} \mathrm{C}$ and relative humidity of $66.6 \pm 3.3 \%{ }^{(1)}$.

\begin{tabular}{lccc}
\hline Genotype & $\mathrm{L}^{* *}$ & $\mathrm{a}^{*}$ & $\mathrm{~b}^{\mathrm{ns}}$ \\
\hline Cigana Preta & $49.51 \mathrm{~b}$ & $-13.59 \mathrm{a}$ & 20.85 \\
Ecuador 72 & $49.76 \mathrm{~b}$ & $-14.59 \mathrm{a}$ & 19.61 \\
F1 011 & $47.86 \mathrm{c}$ & $-11.69 \mathrm{~b}$ & 19.45 \\
F2 015 & $52.67 \mathrm{a}$ & $-13.74 \mathrm{a}$ & 21.41 \\
F3 008 & $52.27 \mathrm{a}$ & $-13.81 \mathrm{a}$ & 20.06 \\
F4 002 & $52.79 \mathrm{a}$ & -12.76 & 20.01 \\
PE 001 & $51.02 \mathrm{a}$ & $-13.551 \mathrm{a}$ & 18.43 \\
FLA 003 & $46.99 \mathrm{c}$ & $-13.75 \mathrm{a}$ & 20.60 \\
\hline Coefficient of variation $(\%)$ & 4.81 & 12.46 & 14.00 \\
Standard deviation & \pm 2.42 & \pm 1.67 & \pm 2.81 \\
\hline
\end{tabular}

${ }^{(1)}$ Means followed by different letters, in the columns, indicate that the genotypes belong to different groups by the Scott-Knott test, at 5\% probability. $*$ and ${ }^{*}$ Significant at 5 and $1 \%$ probability by the $\mathrm{F}$ test, respectively. ${ }^{n s}$ Nonsignificant. L, a, b: L, intensity of the luminosity reflected by the surface; a, intensity of green; and b, intensity of yellow. 
were statistically lower than those of the remaining genotypes. The same two genotypes belonged to the group that was less preferred for oviposition, similarly to that observed by Hasanuzzaman et al. (2016) and Prado et al. (2015) evaluating B. tabaci on eggplant and cotton varieties, respectively, so that the lower the total leaf brightness, the lesser the oviposition.

\section{Conclusions}

1. The 'Ecuador 72' and F4 002 Manihot genotypes show a higher mortality and a longer development period of the immature phase of the whitefly (Aleurothrixus aepim), respectively.

2. The wild accession FLA 003 and the hybrids F1 011 and PE 001 are less preferred for oviposition and show antixenosis resistance to A. aepim.

3. The genotypes 'Ecuador 72', FLA 003, F1 011, and PE 001 can be used to obtain new cassava cultivars for resistance to the whitefly A. aepim.

\section{Acknowledgments}

To Coordenação de Aperfeiçoamento de Pessoal de Nível Superior (Capes), to Empresa Brasileira de Pesquisa Agropecuária (Embrapa), and to Universidade Federal do Recôncavo da Bahia (UFRB), for financial support and scholarship granted.

\section{References}

AKINBO, O.; LABUSCHAGNE, M.; FREGENE, M. Introgression of whitefly (Aleurotrachelus socialis) resistance gene from F1 inter-specific hybrids into commercial cassava. Euphytica, v.183, p.19-26, 2012. DOI: 10.1007/s10681-011-04368.

ANDERSON, P.K; MORALES, F. (Ed.). Whitefly and whiteflyborne viruses in the tropics: Building a knowledge base for global action. Cali: Ciat, 2005. 351p. (Ciat, n.341).

BELlOTTI, A.; CAMPO, B.V.H; HYMAN, G. Cassava production and pest management: present and potential threats in a changing environment. Tropical Plant Biology, v.5, p.39-72, 2012. DOI: 10.1007/s12042-011-9091-4.

BELLOTTI, A.C. Cassava pests and their management. In: Capinera, J.L. (Ed.). Encyclopedia of Entomology. 2.ed. Dordrecht: Springer, 2008. p.764-794. DOI: 10.1007/978-1-40206359-6_531.

BELLOTTI, A.C.; ARIAS, B. Host plant resistance to whiteflies with emphasis on cassava as a case study. Crop Protection, v.20, p.813-823, 2001. DOI: 10.1016/S0261-2194(01)00113-2.
BERLINGER, M.J. Host plant resistance to Bemisia tabaci. Agriculture, Ecosystems and Environment, v.17, p.69-82, 1986. DOI: $10.1016 / 0167-8809(86) 90028-9$.

BOAVENTURA, V. de J.; RINGENBERG, R.; LEDO, C.A. da S. Genetic dissimilarity for resistance to Mononychellus tanajoa (Bondar) (Acari, Tetranychidae) among domesticated and wild Manihot species. Acta Scientiarum. Agronomy, v.37, p.441-446, 2015. DOI: 10.4025/actasciagron.v37i4.19359.

BOIÇA JR., A.L.; CAMPOS, Z.R.; LOURENÇÃO, A.L.; CAMPOS, A.R. Adult attractiveness and oviposition preference of Bemisia tabaci (Genn.) (Homoptera: Aleyrodidae) B-biotype in cotton genotypes. Scientia Agricola, v.64, p.147-151, 2007. DOI: 10.1590/S0103-90162007000200007.

BURBANO M., M.; CARABALÍ M., A.; MONTOYA L., J.; BELLOTTI, A.C. Resistencia de especies de Manihot a Mononychellus tanajoa, (Acariformes), Aleurotrachelus socialis y Phenacoccus herreni (Homoptera). Revista Colombiana de Entomología, v.33, p.110-115, 2007.

CARABALÍ, A.; BELLOTTI, A.C.; MONTOYA-LERMA, J.; FREGENE, M. Manihot flabellifolia Pohl, wild source of resistance to the whitefly Aleurotrachelus socialis Bondar (Hemiptera: Aleyrodidae). Crop Protection, v.29, p.34-38, 2010a. DOI: 10.1016/j.cropro.2009.08.014.

CARABALÍ, A.; BELLOTTI, A.C.; MONTOYA-LERMA, J.; FREGENE, M. Resistance to the whitefly, Aleurotrachelus socialis, in wild populations of cassava, Manihot tristis. Journal of Insect Science, v.10, art.170, p.1-10, 2010b. DOI: 10.1673/031.010.14130.

DUDAREVA, N.; NEGRE, F.; NAGEGOWDA, D.A.; ORLOVA, I. Plant volatiles: Recent advances and future perspectives. Critical Reviews in Plant Sciences, v.25, p.417-440, 2006. DOI: 10.1080/07352680600899973.

EVANS, G.A. The whiteflies (Hemiptera: Aleyrodidae) of the world and their host Plants and natural enemies. Beltsville: USDA, 2008. 703p.

GAZOLA, D.; RHEINHEIMER, A.R.; BELLON, P.P.; MIRANDA, A.M.; SCHERER, W.A.; PIETROWSKI, V.; ALVES, L.F.A. Biologia de Aleurothrixus aepim Goldi (Hemiptera: Aleyrodidae) em mandioca. Revista Raízes e Amidos Tropicais, v.5, p.270-274, 2009.

HASANUZZAMAN, A.T.M.; ISLAM, M.N.; ZHANG, Y.; ZHANG, C-Y.; LIU, T-X. Leaf morphological characters can be a factor for intra-varietal preference of whitefly Bemisia tabaci (Hemiptera: Aleyrodidae) among eggplant varieties. PLoS ONE, v.11, e0153880, 2016. DOI: 10.1371/journal.pone.0153880.

LARA, F.M. Princípios de resistência de plantas a insetos. São Paulo: Ícone, 1991. 336p.

MAFFEI, M.E. Sites of synthesis, biochemistry and functional role of plant volatiles. South African Journal of Botany, v.76, p.612-631, 2010. DOI: 10.1016/j.sajb.2010.03.003.

MARSARO JÚNIOR, A.L.; RACCA FILHO, F.; RAGA, A.; COSTA, V.A. New records of whiteflies (Hemiptera: Aleyrodidae) in Rio Grande do Sul State, Brazil. Idesia, v.33, p.143-145, 2015. DOI: $10.4067 / \mathrm{S} 0718-34292015000100015$. 
MOREAU, T.L.; ISMAN, M.B. Trapping whiteflies? A comparison of greenhouse whitefly (Trialeurodes vaporariorum) responses to trap crops and yellow sticky traps. Pest Management Science, v.67, p.408-413, 2011. DOI: 10.1002/ps.2078.

PRADO, J.C. do; PEÑAFLOR, M.F.G.V.; CIA, E.; VIEIRA, S.S.; SILVA, K.I.; CARLINI-GARCIA, L.A.; LOURENÇÃO, A.L. Resistance of cotton genotypes with different leaf colour and trichome density to Bemisia tabaci biotype B. Journal of Applied Entomology, v.140, p.405-413, 2015. DOI: 10.1111/jen.12274.

RIBEIRO, T.F.L. Semioquímicos envolvidos na interação canade-açúcar $x$ broca gigante e mandioca $x$ percevejo-de-renda $x$ mosca-branca. 2015. 64p. Dissertação (Mestrado) - Universidade Federal de Alagoas, Maceió.

SHIMODA, M.; HONDA, K. Insect reactions to light and its applications to pest management. Applied Entomology and Zoology, v.48, p.413-421, 2013. DOI: 10.1007/s13355-013-0219-x.
SILVEIRA NETO, S.; NAKANO, O.; BARBIN, D.; VILLANOVA, N.A. Manual de ecologia dos insetos. São Paulo: Agronômica Ceres, 1976. 420p.

SLANSKY JR, J.; SCRIBER, J.M. Food consumption and utilization. In: KERKUT, G.A.; GILBERT, L.I. (Ed.). Comprehensive insect physiology, biochemistry and pharmacology. Oxford: Pergamom Press, 1985. v.4, p.87-163. DOI: 10.1016/B978-0-08-030805-0.50009-2.

TORRES, L.C.; SOUZA, B.; AMARAL, B.B.; TANQUE, R.L. Biologia e não-preferência para oviposição por Bemisia tabaci (Gennadius.) biótipo B (Hemiptera: Aleyrodidae) em cultivares de algodoeiro. Neotropical Entomology, v.36, p.445-453, 2007.

VAN LENTEREN, J.C.; NOLDUS, L.P.J.J. Whitefly-plant relationships: behavioural and ecological aspects. In: GERLING, D. (Ed.). Whiteflies: their bionomics, pest status and management. Hants: Intercept, 1990. Cap. 3, p.47-90.

Received on June 28, 2017 and accepted on November 9, 2017 